\title{
Does Senior High School Strand Matter in Nursing Students' Academic Self- Regulated Learning and Academic Performance?
}

\author{
Xerxes G. Malaga' ${ }^{1}$, Ryan Michael F. Oducado²
}

1 Negros Occidental Comprehensive Health Program, Philippines

2 West Visayas State University, Philippines

\section{Article Info}

\section{Article History:}

Submit Jan 25th, 2021

Accepted March 6th, 2021

Published March 28th 2021

\section{Keywords:}

Academic performance; High school strand; Nursing; Selfregulated learning; Students

\section{INTRODUCTION}

Education expands our vision and outlook of the world. Hence, it is no wonder that many countries including the Philippines are in the molding process of making education the primary asset the country could have. Not so long ago, the Philippine Basic Education implemented K-12 Curriculum that has been legalized by the Republic Act 10533.1 The Republic Act No.

\section{Abstract}

The Philippines recently adopted the $\mathrm{K}$ to 12 program in basic education. Under this program, students can choose their track and strand relative to their interests or career choices when they reach senior high school. However, issues surfaced when the K to 12 graduates were admitted to the college courses not aligned with the strand they have completed. This crosssectional study was conducted to determine the difference in the academic self-regulated learning and performance of the STEM (Science and Technology, Engineering, and Mathematics) and non-STEM graduates in senior high school among freshmen nursing students in a city-subsidized college in the Philippines. The Academic Self-Regulation Learning Scale and grades of students in the first semester were used and analyzed in this study. Results showed that there was a significant difference in the academic selfregulated learning $(p=0.045)$ and academic performance $(p=0.000)$ of freshmen nursing students when grouped according to their senior high school strand. The STEM graduates had significantly higher academic selfregulated learning and academic performance than the non-STEM completers. Unfortunately, no significant relationship was established between academic self-regulated learning and academic performance $(p=0.559)$. Students who are graduates of the STEM strand from senior high school appear to be better prepared to take up the nursing course. Colleges of nursing may consider the academic strand of students in senior high school when admitting students in the nursing program.

Corresponding author:

Ryan Michael F. Oducado

rmoducado@wvsu.edu.ph

South East Asia Nursing Research, Vol 3 No 1, March 2021

ISSN:2685-032X

DOI: $\underline{\text { https://doi.org/10.26714/seanr.3.1.2021.1-7 }}$

10533 (2013) otherwise known as the Enhanced Basic Education Act of 2013 adds two years of senior high school education. High school now has two divisions: the junior and senior high school, and students in the country must pass through the two divisions to earn a high school diploma and qualify to enter college or university. Under this program, students are to choose their own track or strand according to their preference, or field of interest, or decide to 
venture out employment for the next two years of senior high school education. The senior high school students undertake a standard core curriculum and can choose from four tracks of specialization: Academic, Technical-Vocational and Livelihood (TVL), Sports, and Arts and Design. ${ }^{3}$ These tracks are specific areas of study similar to college courses. ${ }^{4}$ The academic track is further divided into four strands: Science, Technology, Engineering, and Mathematics (STEM); Accountancy, Business, and Management (ABM); Humanities and Social Sciences (HUMSS); and General Academic. ${ }^{3}$

Having an ideal strand offer learners a sense of self-assurance and can help students to be passionate about their chosen career. ${ }^{5}$ Alignment to the chosen college course was the main reason of students enrolling in the STEM strand. ${ }^{6}$ Besides, a study found that STEM status significantly predicted retention and graduation outcomes. ${ }^{7}$ Poor adjustment and academic performance to the health science courses also contribute to dropout rates of students. ${ }^{8}$ However, the Commission on Higher Education (2017) in the Philippines released a memorandum order indicating that all Grade 12 senior high school graduates are eligible to enter college irrespective of the strand or track they have taken in senior high school. ${ }^{9}$ The problem arises when the $\mathrm{K}$ to 12 graduates are to pursue a college degree that is not related to the strand they finished during their senior high school years. Difficulties arise in a sense that that the subjects taken in senior high school are not aligned to the desired academic program, or the skills and knowledge learned by the students in senior high school might not be enough to compensate to the demands of the chosen college degree. ${ }^{10}$

Thus, this study was conducted to determine if there were significant differences in academic performance of $\mathrm{K}$ to 12 graduates specifically from the STEM and non-STEM strand as they unveil their college journey into nursing as their chosen college academic program. It is imperative for nursing educators to understand and regularly assess the academic performance of students. ${ }^{11}$ Research on students' academic performance or academic achievement is important because it is one of the indicators of students' success in learning. ${ }^{12-14}$ Moreover, academic and career guidance are among the expressed guidance needs of nursing students. ${ }^{15}$ Helping students understand their likely success in their chosen college degree is thereby necessary.

Meanwhile, knowing the concept of selfregulated learning is necessary in today's social and academic world. ${ }^{16}$ Self-regulated learning has been applauded as the key competence to lifelong learning. ${ }^{17}$ Despite being a well-studied topic in the fields of psychology and education, limited research focused on its relationship to the academic performance of nursing students. Understanding self-regulation is essential in the development of students' capabilities and achievement. ${ }^{16}$ In this study, we also investigated the relationship between selfregulated learning and academic performance among nursing students.

\section{METHODS}

The research design utilized in the study was cross-sectional research. This study was conducted among 112 freshmen or first-year nursing students in a citysubsidized college in the Western Visayas region of the Philippines.

The instrument used was the Academic SelfRegulated Learning Scale (A-SRL-S) developed by Magno (2010) to measure self-regulation within the context of students' learning in higher education. Each item is scaled using a four-point Likert scale (1-Strongly disagree to 4-Strongly agree). The A-SRL-S contains 54 items with seven (7) subscales. The scale has been reported to have high validity and reliability measures when tested among Filipino college students. The internal consistency of 
the seven subscales was between 0.70 and $0.84{ }^{18}$. For this study, the A-SRL-S has an overall reliability of Cronbach's alpha 0.95. The survey questionnaires were distributed personally to the students of the said department after their lecture classes. Directions were given as to how to answer and fill up the survey instrument. The whole content of the survey instrument was discussed before the participants can answer the questionnaires to avoid confusion. After signing the informed consent forms, the respondents were given ample time (30 minutes) to fill up the said questionnaires. Afterwards, the researchers personally retrieved the said questionnaires then checked for completeness of responses.

The academic performance of students was measured using their actual grades in the first semester of the academic year 20182019 taken from the Office of the Registrar with permission from the college dean and after participants consented to partake in the study. A demographic profile sheet was also used to collect pertinent demographic data and identify the academic strand of students. In this study, the students were categorized as either STEM or non-STEM strand (includes ABM, HUMSS, and general academic strands of the academic track and other tracks).

Data analysis was carried out using SPSS version 23. Mean, standard deviation, frequency, and percentage were used for descriptive analysis. Mann-Whitney U test was employed to determine significant differences while Spearman's rho was utilized to measure the relationship between academic self-regulation and performance. Alpha level of significance was set at 0.05 .

\section{RESULTS}

Table 1 present the profile of the participants. The average age of freshman nursing students was $18.86 \quad(\mathrm{SD}=0.73)$ years. The majority (83.9\%) of the students were females. Most (81.2\%) students belonged to families with an average monthly salary of 15,780 pesos/month or less. A little over half (51.8\%) had 4 or more siblings. A little over two-thirds (68.7\%) were graduates of the non-STEM strand in senior high school.

Table 2 shows that the composite mean score of nursing students in the A-SRL-S was 3.31 ( $\mathrm{SD}=0.53$ ). The mean score of the graduates of the STEM strand and nonSTEM strand were $3.35(\mathrm{SD}=0.34)$, and 3.29 $(\mathrm{SD}=0.53)$, respectively. Moreover, the mean average grade reflecting the academic performance of first-year nursing students in the first semester was 91.35 (SD=0.67). The mean average grade of the graduates of the STEM strand and non-STEM strand were 92.39(SD=1.32), and $90.87(\mathrm{SD}=1.60)$, respectively.

Table 3 shows that there was a significant difference in academic self-regulated learning and academic performance of freshmen nursing students based on their senior high school strand. Graduates of the STEM strand were significantly more $(\mathrm{p}=0.045) \quad$ self-regulated learners compared to the graduates of the non-STEM strand. At the same time, graduates of the STEM strand had a significantly higher $(p=0.000)$ academic performance than the graduates of the non-STEM strand.

Table 4 shows that there was no significant relationship $(\mathrm{p}=0.559)$ between academic self-regulated learning and academic performance of freshman nursing students. 
Table 1

Profile and strand in High School

\begin{tabular}{|c|c|c|c|c|}
\hline & $\mathrm{M}$ & SD & $\mathrm{f}$ & $\%$ \\
\hline Age (years) & 18.86 & 0.73 & & \\
\hline \multicolumn{5}{|l|}{ Sex } \\
\hline Male & & & 18 & 16.1 \\
\hline Female & & & 94 & 83.9 \\
\hline \multicolumn{5}{|l|}{ Monthly family income } \\
\hline Less than 7,890/Month & & & 52 & 46.4 \\
\hline Between 7,890 to $15,780 /$ Month & & & 39 & 34.8 \\
\hline Between 15,781 to $31,560 /$ Month & & & 17 & 15.2 \\
\hline Above $31,561 /$ month & & & 4 & 3.6 \\
\hline \multicolumn{5}{|l|}{ Number of siblings } \\
\hline 3 or less & & & 45 & 40.2 \\
\hline 4 or more & & & 58 & 51.8 \\
\hline No siblings & & & 9 & 8.0 \\
\hline \multicolumn{5}{|l|}{ Senior high school (SHS) strand } \\
\hline STEM & & & 35 & 31.3 \\
\hline Non-STEM & & & 77 & 68.7 \\
\hline
\end{tabular}

Table 2

Academic self-regulation and academic performance

\begin{tabular}{lcccccc}
\hline \multirow{2}{*}{ Variables } & \multicolumn{2}{c}{ General } & \multicolumn{2}{c}{ STEM } & \multicolumn{2}{c}{ Non-STEM } \\
\cline { 2 - 7 } & $\mathrm{M}$ & $\mathrm{SD}$ & $\mathrm{M}$ & $\mathrm{SD}$ & $\mathrm{M}$ & SD \\
\hline Academic self-regulated learning & 3.31 & 0.53 & 3.35 & 0.34 & 3.29 & 0.53 \\
Academic performance & 91.35 & 0.67 & 92.39 & 1.32 & 90.87 & 1.60 \\
\hline
\end{tabular}

Table 3

Differences in academic self-regulated learning and performance

\begin{tabular}{lcccccc}
\hline \multirow{2}{*}{ Variables } & \multicolumn{2}{c}{ Academic self-regulated learning } & \multicolumn{2}{c}{ Academic performance } \\
\cline { 2 - 6 } SHS strand & Mean Rank & U & p-value & Mean Rank & U & p-value \\
\cline { 2 - 6 } STEM & 65.63 & 1028.0 & 0.045 & 77.41 & 615.5 & 0.000 \\
Non-STEM & 53.45 & & & 46.99 & & \\
\hline
\end{tabular}

Table 4

Academic self-regulation and academic performance

\begin{tabular}{lcc} 
& & \\
\hline Variables & Correlation coefficient & p-value \\
\hline Academic self-regulation and performance & -0.050 & 0.599 \\
\hline
\end{tabular}

\section{DISCUSSION}

This study investigated the difference in academic self-regulated learning and academic performance among nursing students between graduates of STEM and non-STEM strand. This study came about after observing students who were nonSTEM completers were struggling in their science and nursing courses. It has also been observed that their grades were lower in these courses. On the other hand, STEM completers have shown remarkable grades in their science and nursing courses.

In this study, we found that the academic self-regulated learning and performance of nursing students varied according to their senior high school academic strand. Ideally, STEM completers are supposed to enroll in nursing. Their track and strand are geared towards learning the foundations of academic subjects aligned with the nursing program. Our results also indicate that 
graduates of the STEM strand had a higher academic self-regulation suggesting that these students are better in terms of planning and organizing, goal-setting, selfevaluation, memory strategy, learning responsibility, seeking assistance, and environmental structuring. Similar findings were reported in prior studies. Graduates of the STEM academic strand had a significantly higher academic performance compared to the non-STEM strand graduates. A significant difference in the academic adjustment and performance of freshmen students from different health science disciplines in the Philippines was similarly noted in another study. ${ }^{19}$ A study among engineering students likewise found a significant difference in the Calculus 1 performance between students from the STEM and non-STEM strands. ${ }^{4}$ Students from the STEM strand also performed better academically in the Applied Chemistry course. ${ }^{20}$ Our findings seem to indicate that the STEM graduates are likely to succeed in the nursing program with minor difficulties and adjustments as compared to their non-STEM counterparts. In addition, our results seem to point out that the $\mathrm{K}$ to 12 program of the Philippines plays a significant role in preparing senior high school students for their chosen career path if followed appropriately.

Moreover, our study demonstrated no correlation between academic selfregulation and academic performance among freshmen nursing students. No significant correlation between selfregulation and educational performance among public university students was also reported by Sahranavard, Miri, \& Salehiniya (2018). ${ }^{21}$ No relationship between academic self-regulation and their academic performance was also disclosed in a study among senior high school students in the Philippines. $^{22}$ High self-regulation did not predict school ability in another study. ${ }^{23}$ It has also been noted that not all selfregulated learning strategies exerted the same influences on academic achievement and a decreasing trend on the effect size between self-regulated learning and academic achievement was observed. ${ }^{17}$ However, our result is contrary to other studies conducted in other disciplines. A weak positive association between selfregulated learning and academic achievement was found among undergraduate medical students. ${ }^{13}$ A study among preparatory school students at Cag University in Mersin, Turkey revealed that the more students use self-regulation strategies, the more likely they become academically successful. ${ }^{24}$ Self-regulation of learning and achievement were significantly correlated among the undergraduate program in the Faculty of Psychology at Padjadjaran University. ${ }^{25}$ Four of five domains of self-regulated learning had a positive impact on academic performance of students in another study. ${ }^{26}$ The variation in findings may be attributed to the different measures used to assess self-regulated learning between studies and also to the relatively limited sample of our study. Nonetheless, further research is required to confirm our findings. It is argued that self-regulated learning is a complex phenomenon hence, future scholars need to pay more attention to the different dimensions of self-regulated learning in relation to academic achievement. ${ }^{16}$

This research has limitations. This study only included first-year nursing students in one nursing school in the Philippines who were enrolled in the academic year 20182019. Findings cannot be generalized in all schools and students locally and in other countries. Also, this study is limited to the academic performance of students in one semester only. Future researchers may compare the difference between strands upon completion of the degree. Furthermore, our research relied only on self-administered questionnaires for data collection and the cross-sectional research design of our research cannot establish a causal effect of the independent variable to the outcome variable. Nonetheless, this 
research has contributed to the limited but growing research on the topic.

\section{CONCLUSION}

The strand or track of students in senior high school influences their academic selfregulated learning and academic performance. Students' stranding in senior high school has prepared them for a better transition in college especially in the nursing program. Students who are graduates of the academic STEM strand from senior high school appear to be more prepared to take up the nursing course, better able to cope with the demands of the course, and are likely to excel in the nursing school. Our study recommends that high school students should be given proper career guidance relative to the course they intend to take in college. Likewise, colleges of nursing may consider the academic strand of students in senior high school when admitting students in the nursing program. Moreover, our study suggests that added attention and guidance must be provided to non-STEM students admitted in the undergraduate nursing program.

\section{ACKNOWLEDGMENTS}

The authors are grateful to their participants.

\section{CONFLICTS OF INTEREST}

Neither of the authors has any conflicts of interest that would bias the findings presented here.

\section{REFERENCES}

1. Rabacal JS, Alegato CC. K-12 STEM track in one public secondary school: Opportunities and challenges. Asia Pacific J Multidiscip Res. 2017;5:28-33.

2. Republic Act No. 10533. An act enhancing the Philippine basic education system by strengthening its curriculum and increasing the number of years for basic education, appropriating funds therefor and for other purposes. 2013.
3. Development Asia. Factors affecting senior high school track offerings in the Philippines. 2019.

4. Molina MG. Comparison of the calculus 1 performance of engineering students from STEM and non-STEM SHS strands. PUPIL Int J Teaching, Educ Learn. 2019;3:103-23.

5. Magdadaro LRP. Passion-based vs. practicalbased preference of strand in senior high school. Int J Acad Res Bus Soc Sci. 2020;10.

6. Rafanan RJL, De Guzman CY, Rogayan D V. Pursuing stem careers: Perspectives of senior high school students. Particip Educ Res. 2020;7:38-58.

7. Whalen D, Shelley M. Academic success for STEM and non-STEM majors. J STEM Educ. $2010 ; 11$.

8. McFarland, Stark, Cui. Trends in high school dropout and completion rates in the United States: 2014. 2016.

9. Commission on Higher Education. CHED memorandum order no. 105 series of 2017: Policy on the admission of SHS graduates to the higher education institutions effective academic year 2018-2019. 2017.

10. Magtibay RG, Los Baños Z. The effect of K to 12 strand on first year BIT food technology students in pursuing their higher education. Int J Recent Innov Acad Res. 2019;3:39-46.

11. Oducado RMF. Are nursing students' early course and perceived performance related to their final and actual course performance? Nurse Media J Nurs. 2019;9:167-75.

12. Oducado RMF, Penuela AC. Predictors of academic performance in professional nursing courses in a private nursing school in Kalibo, Aklan, Philippines. Asia Pacific J Educ Arts Sci. 2014;1:21-8.

13. Ningrum RK, Kumara A, Prabandari YS. The relationship between self-regulated learning and academic achievement of undergraduate medical students. In: IOP Conference Series: Materials Science and Engineering. Institute of Physics Publishing; 2018. p. 012155.

14. Oducado RMF, Sotelo MG, Ramirez LMM, Habaña MP, Belo-Delariarte RG. English language proficiency and its relationship with academic performance and the nurse licensure examination. Nurse Media J Nurs. 2020;10:4656.

15. Oducado RMF, Frigillano PRS, Gunce JJT, Jover PLB, Meliton PN, Pangilinan KT. Guidance needs of nursing students in Iloilo City, Philippines. PEERS Inc. 2017;1:35-47.

16. Xiao S, Yao K, Wang T. The relationships of selfregulated learning and academic achievement 
in university students. SHS Web Conf. 2019;60:01003.

17. Li J, Ye H, Tang Y, Zhou Z, Hu X. What are the effects of self-regulation phases and strategies for Chinese students? A meta-analysis of two decades research of the association between self-regulation and academic performance. Vol. 9, Frontiers in Psychology. Frontiers Media S.A.; 2018.

18. Magno C. Assessing academic self-regulated learning among Filipino college students: The factor structure and item fit. Int J Educ Psychol Assess. 2010;5:61-76.

19. Alipio M. Academic adjustment and performance among Filipino freshmen college students in the health sciences: Does senior high school strand matter? 2020;

20. Magtibay RG, Caballes DG. The K to 12 strands taken by first year BIT food technology students and its effect on their academic performance in applied chemistry. . Int J Recent Innov Acad Res. 2019;3:39-46.

21. Sahranavard S, Miri MR, Salehiniya H. The relationship between self-regulation and educational performance in students. J Educ Health Promot. 2018;7:154.

22. Abun D, Magallanes T. Academic self-regulation of STEM of senior high school students of Divine Word Colleges in Region I, Philippines and their academic performance. TEXILA Int J Acad Res. 2018;5:14-30.

23. Johny L, Lukose L, Magno C. The assessment of academic self-regulation and learning strategies: Can they predict school ability? Educ Meas Eval Rev. 2012;3:75-86.

24. Yeniçıkan S. The relationship between selfregulation strategies and academic achievement at a university context. Çă Üniversitesi Sosyal Bilimler Enstitüsü; 2020.

25. Agustiani H, Cahyad S, Musa M. Self-efficacy and self-regulated learning as predictors of students academic performance. Open Psychol J. 2016;9:1-6.

26. Ejubović A, Puška A. Impact of self-regulated learning on academic performance and satisfaction of students in the online environment. Knowl Manag E-Learning An Int J Knowl Manag E-Learning. 2019;11:345-63. 